\title{
Landless Agricultural Labourers' Asset Strategies
}

\author{
Judith Heyer
}

\section{Introduction}

This article focuses on asset strategies of landless labourers in a South Indian context. These are people who suffer from chronic poverty and vulnerability.

Asset strategies of the poor are a neglected area in India as elsewhere, despite the fact that since the early 1970 s there has been a substantial programme of government intervention to improve the asset positions of India's poor. Some of the reasons why asset strategies of the poor have not been taken seriously are (a) because the poor are thought of as basically assetless; (b) because increasing the assets of the poor is thought to be a relatively low priority; (c) because increasing the assets of the poor is thought to be fruitless; (d) because it is felt that it is obvious what is needed - there is no need for further studies of the situation. But (a) the poor do have assets that are often quite crucial to them, and to understanding their behaviour and their predicament; (b) there may be higher priorities, but assets may be a priority too; (c) there have been some notable successes with policies designed to increase the assets held by the poor; (d) what seems obvious is often wrong. Some of these points are addressed in this article.

There has been a good deal of debate in the Indian literature on the array of policies aimed at strengthening the position of landless agricultural labourers. One of the debates has centred on the relative merits of employment generation versus schemes to improve landless agricultural labourers' asset positions. Another has revolved around the argument about whether more fundamental changes in the structure of both production itself and production relations are essential to produce the massive increases in employment and labour productivity that are needed to make serious inroads into the problem of landless agricultural labourer poverty.'

Agricultural labourer households made up an estimated 31 per cent of all rural households in India in 1983 and the proportion has been increasing [Unni 1988]. It is important to consider how the position of agricultural labourers can be improved as labourers,

See, for example, Guhan 1980, 1986; Rath and Hatao 1985; Dantwala and Hatao 1985; Hirway and Hatao 1985; Subbarao 1985; Parthasarathy 1985; Prasad 1985; Kurian 1987; Rao and Erappa 1987; Bandophadhyay 1988. as well as what can be done to enable agricultural labourers to move into other occupational categories. Increases in the demand for labour are crucial. Supply side factors are also important, however, and these have received less attention. This article concentrates on some of the supply side factors, more specifically on what individual labourers can do through investment strategies to strengthen their positions. ${ }^{2}$ Looking at the investment behaviour of landless agricultura! labourers in South India raises questions relevant to the strategies of poor people in general. There are parallels between the situation of these landless agricultural labourers and poor people more generally.

An examination of the asset positions of landless agricultural labourers, and the priorities that landless agricultural labourers attach to the acquisition of more of particular kinds of assets, helps to explain why the results of many of the Indian government programmes designed to help poor people to acquire more assets have been so disappointing, at least as far as landless agricultural labourers are concerned. One can take the view that these programmes were never intended as more than weak palliatives in the first place, or even that they were designed to make it possible to continue to exploit the poor more effectively. But if one takes the view that they were intended to achieve at least some improvement, the lack of understanding of the roles that (particular) assets play, and the lack of appreciation of the difficulties that landless agricultural labourers face in using the assets available to them, must be seen as real obstacles to the effectiveness of the government interventions.

The most important asset as far as landless agricultural labourers are concerned is labour power. The quantity and quality of labour power is influenced by investments, some of which are not normally recognised as 'productive'. Investment in housing may be crucial, as also invest ment in education. Investment in marriages and health can be important too. These often compete with investments that are more commonly recognised as 'productive'.

The more obviously 'productive' assets with which

2 There is of course some work on assets and asset strategies of the poor in India, notably the work by N. S. Jodha, (for example, Jodha forthcoming). See also Sivakumar 1978; Chambers and Leach 1987. 
landless agricultural labourers in India are concerned are livestock. carts and ploughs, and tools and equipment associated with the supply of services and petty manufacturing. There is a whole range of government programmes designed to help landless labourers, among others, to make more of these investments. However, landless agricultural labourers often have rather limited access to these programmes. and even when they do get access it can be difficult for them to generate returns from the investments they undertake.

In a 1981-82 study of villages in Coimbatore district in Tamil Nadu. I looked at the major expenditures of landless agricultural labourers. One of the questions that arose was why they were not spending their "surpluses" on more obviously productive investments. but spending them instead on so many investments that appeared to be less productive. There is always a certain amount of differentiation. even among landless labourers, if only through variations in dependency ratios. Some landless agricultural labourers in the Coimbatore villages were markedly better off than others. But they seemed to be making no attempt to acquire assets such as livestock. tools. equipment or land. They seemed to be doing better as agricultural labourers. "investing' in their agricultural labouring, than they would by acquirirg land or other assets that might enable them to establish different occupational positions. Many of the conventionally recognised 'productive' investments seemed not to be productive for them.

\section{The Context}

The evidence discussed in this paper comes from villages in an area in which agriculture is relatively dynamic. and there are nearby urban areas in which employment growth has been considerable. The villages are $40-60 \mathrm{~km}$ north-east of Coimbatore, an industrial town of around one million people. dominated by textile mills and light engineering. There are also several smaller towns in the neighbourhood. An enormous variety of crops is grown on weil-fed land, on which sugar and cotton predominate. Groundnuts and sorghum are grown quite widely on rain-fed land as well. There is a shortage of water. which makes paddy a very minor crop. Agriculture is very commercialised. with high levels of application of purchased inputs. a large a mount of wage labour, and up to date crop varieties and production techniques. It is an area in which livestock play an important role. There is very little mechanical cultivation. but irrigation is virtually all electrified.

The villages are dominated by groups of larger farmers from Gounder and Naidoo castes. with up to 30 acres of land each. The landless agricultural labourers, who made up 31 per cent of the 1981-82 population, are chakkiliyans, panadis, and lower caste hindus. Agricult ural labourers are employed almost exclusively within their own villages. The exception is sugar-cane crushing. on which groups of agricultural labourers spend several weeks at a time in other parts of the district.

The fieldwork on which much of the evidence in this article is based involved interviewing a 20 per cent random sample of 233 houscholds of all occupational categories in six hamlets over a period of six months. There were 73 landless agricultural labourer households in the sample. (and a further 14 agricultural labourers with very small areas of land). A number of non-sample households were also interviewed.

There was no attempt to emphasise the position of women, as opposed to men. in the original study. The whole discussion is thus somewhat male centred.

Landless agricultural labourers in these villages are not as poor as in some parts of Tamil Nadu and the rest of India. The relatively tight labour market is reflected in relatively high earnings. Daily wage rates are low: they were Rs.6-7 for men. and Rs.2-3 for women in 1982, roughly equivalent to $2 \mathrm{kgs}$ of rice for men and less than $1 \mathrm{~kg}$ of rice for women for a day`s work. But earnings are higher than these figures suggest because there is relatively little seasonal unemployment. Permanent agricultural labourers were getting between Rs. 1800 and Rs. 2400 per year in 1982. This would have been the equivalent of $300-400$ days of work at a daily rate of Rs.6 over a year. Despite these earnings however. less than 10 per cent of the households had bicycles, virtually none had bullocks. none had ploughs or carts. and very few had even tiny pieces of land.

Differentiation still follows caste lines very closely. All chakkiliyans and all panadis are agricultural labourers. except those with official government positions. No chakkiliyan or panadi household has more than a very small piece of land: most have no land at all. Political alliances are vertical, and collective acticn runs along vertical. not horizontal lines. It is easy to see why agricultural labourers are unwilling to risk straining relationships with employers: wages are virtually their only sources of income, help from employers in times of adversity is crucial. perks from employers are important. Employers are the only route to the administration. But it is not easy to explain why in other areas. apparently quite similar. landless agricultural labourers are so much more politically conscious and organised. ${ }^{3}$

The villages were originally chosen for study because they had some of the highest uptakes of Small Farmer Development Agency (SFDA) loans in Coimbatore district. They were villages with relatively high levels

"There is an extensive Indian literature on this question. See Rudra 1987 for a specific example of the point. 
of direct intervention in the latc 1970 s and carly 1980 s. In the event. however. therc was a conspicuous abstence of interventions that reached agricultural labourers. and there was not much evidence of interventions reaching other disadvantaged groups cither. There was a Rural Employment Programmo project in the neighbourhood in 198I-82. but none of the beneficiaries were agricultural labourers. Only small or marginal farmers gained acess to the relatively favourable cmployment that this offered in 1981-82. Small and marginal farmors were also the main beneficiaries of the SFDA programme.

\section{Labour Options}

Variations in dependency ratios mean that some households have the potential to earn a "surplus" over and above what they survive on. Thus some households have room for manocuvre. albeit at a very basic level. This room for manocuvre is reflected in more leisure or less arduous work: more consumption: and/or more investment. Evidence of "surpluses' includes (1) decisions to work fewer davs or fewer hours per day. or on less arduous forms of work: (2) substantial expenditures on marriages. housing. etc. for which some landless agricultural labourer households manage to mobilise relatively large sums: and (3) relatively advantageous dependency ratios.

There are a number of different wage labour options. and there are important differences in the way these are used by chakkiliyans. panadis and caste hindus. Thus there is a high incidence of pannayal labour among chakkiliyans, and of sugar-cane crushing labour among panadis. Pannayal labour. "at tached" by the year. at the beck and call of the employer. with no fixed hours or holidays. is the most arduous. least desirable, and best paid. It is something a lot of chakkiliyans do for a while when they are young. A few take it up again when they are older. often for a particular purpose or because they are in difficulty. It is unusual for panadis or caste hindus to take up pannayal labour. though there are those who do. Similarly, while sugar-cane crushing is something that many panadis do. it is much less common among chakkiliyans or caste hindus. The earnings are relatively high. but it involves going away for weeks at a time. and a large proportion of the earnings get spent on the job. The other alternative is casual labouring. ostensibly on a daily basis, although often in practice negotiated and paid by the week. This is associated with the lowest earnings: an adult man earning the top rate of pay would have to work for 343 days to get the equivalent of the top pannayal earnings per year. Casual labourers never work as many days as this.

Other important variables as far as employment is concerned are the age at which children start wage work. and the intensity with which they do this. and the amount of wage work women do. Virtually all women's walge work is casual. There are considerable variations for women at different stages of the life cycle. They may work for a highel or lower proportion of their time at any stage. and they may stop work for longer or shorter periods when they are pregnant, or have young children. or have children that can caln. Women's wages are very much lower than men's. Rs.2-3 por day in 1981-82. compared with Rs.6-7. only partly because they work shorter days. This puts less pressure on them to work. or continue working when therc are rcasons for them not to do so. and vice versa [Josc 1988: Unni 1988: Balrdhan 1985].

Boys. particularly chakkilivan boys. are sent out to work as pannayals when they are as young as seven vears. but more commonly from the age of 10 or 12 . They stalt by herding livestock. and then move gradually to morestrenuous work. with higher rates of pay. as they get older and more experienced. Those that do not work as pannayals start casual work, or sugar-canc crushing. a little older. They often herd houschold livestock before that. Girls start casual work as young als 8 or 10 years. and by the age of 12 or so thcy carn a full female casual worker's wage.

How much a particular houschold earns depends a great deal on its labour strategy. Chakkiliyans tend to earn most. per adult-cquivalent. Panadis' earnings are quite high too. but a substantial proportion of these are consumed away sugar-canc crushing. Caste hindus earn lcast. There are substantial variations within each group. though.

\section{Investment}

'Investment' is defined very broadly here to include anything involving the acquisition or purchase of 'assets' that will bring future returns. It thus includes expenditures on marriage and kinship relationships: ceremonial expenditures, as on temple visits: health expenditures: expenditures on education, training and skills: expenditures on migration: on physical assets. such as land. livestock. tools. equipment. machinery. housing and other buildings. bicycles and other consumer durables; and even expenditures on financial assets and jewelry. Seeing all of the above as important and substantial alternative 'investments" brings out the fact that considerable "investment" is being undertaken by agricultural labourer households, and it plays an important role.

There are some important distinctions to be made however. Some 'investment' does not augment productive potential in the aggregate. although it may do so for individuals. Much marriage expenditure is of this kind. Other 'investment' augments productive potential. possibly by transferring it from one group to another in the society. Some of the livestock acquired by agricultural labourers might otherwise have been maintained by others. This is even more obviously true 
of land. The question then becomes whether in the hands of agricultural labourers these assets are more productive. Equipment often represents a clearer addition to productive capacity for the society as well as the individual. The same is true of housing, in so far as it is associated with health improvements, for example.

Investment may make a direct contribution to quality of life or standard of living. It maly also st rengthen the bargaining positions of landless agricultural labourers, by diversifying their income sources, or improving their ability to survive periods of adversity. The vulnerability of landless agricultural labourers in these villages needs to be emphasised. This still makes for extremely dependent employer-employee relationships. Relationships with employers are crucial in times of adversity: employers can be called upon to pay medical expenses, to help with access to medical care, to provide food and other essential needs, and to help with access to the administration. These can all be critical in times of adversity.

There are noticeable differences between chakkiliyans, panadis and caste hindu labourers in household and other social relationships which have an important bearing on investment decisions and strategies. Thus young chakkiliyan men tend both to contribute to and to benefit from the income of the parental household for much longer in their life-cycles than panadis. Young chakkiliyan men tend to stay at home, earning substantial sums, much of which they contribute to the income of their parental households. They then get help with marriage expenses, and sometimes also with housing, before setting themselves up in independent households. Panadis, on the other hand, do not contribute much to the household in their teenage and early adult years. In turn they seem not to get much help with marriage, or housing, from their parental households. This has important implications for the amount of accumulation that takes place: the additional earnings of teenage and young adult chakkiliyans seem to result in relatively good housing standards, and good marriages, as compared with those of panadis in these villages. They also result in relatively strong asset positions that have a bearing on the living conditions of the families that they sustain.

Other social relationships seem to be important where caste hindus are concerned. Caste hindus benefit from connections with relatively better off households in their castes, and from generally less restricted access to the village community, as compared with chakkiliyans and panadis. They also benefit from the inheritance of better housing. Thus some members of caste hindu labourer households have got jobs in textile mills, set up shops, and even acquired substantial amounts of land in the past. These options do not seem to have been open to members of chakkiliyan or panadi households. Caste and kin connections widen the range of opportunities quite considerably.

\section{Landless Agricultural Labourers' 'Investments'}

1 will now summarise the evidence on some of the major categories of 'investment' among landless agricultural labourers in the Coimbatore villages.

\section{Marriage}

In common with people from all castes and classes in India, agricultural labourers in the Coimbatore villages, go to tremendous lengths to finance marriage outlays. These are important for obtaining access to kin relationships, which bring a whole range of advantages including some forms of insurance. They are also important for obtaining able-bodied wives. Even agricultural labourers that one would think had barely any 'surplus' at all manage to mobilise substantial sums where marriages are concerned. The upper ranges of expenditure for a groom are roughly equivalent to the annual wage of a permanent adult male agricultural labourer. They are also equivalent to the purchase of a milch animal or bullock, an acre of dry land, an average house or a substantial house improvement. For a bride, the expenditure is somewhat less. Only a handful of these agricultural labourer households are involved in a dowry system. Those that are, are almost all caste hindus.

Those who cannot mobilise a substantial sum for marriage postpone, marry a social outcast or a physically disabled person, or marry with in a family or kinship network where some reciprocal arrangement is possible. None remain unmarried beyond the age of 40 , but some wait until they are in their late $30 \mathrm{~s}$, and this is regarded as a considerable hardship. Late marriage makes adverse dependency ratios more likely. It can also make it difficult for the couple to recover its financial position in the years after marriage. There was a marked contrast between chak kiliyans who all married early, and panadis who all married later, some much later, in the study villages. Caste hindus came somewhere in between.

Money is raised for marriage by fathers, mothers, brothers, grooms, or some combination of these, with other close relatives helping as well in some cases. People work more intensively, or under a more arduous but more remunerative contract for a while; sell livestock purchased earlier for the purpose; sell other assets; borrow. Some of the loans are repaid, and asset holdings rebuilt, in the early years of marriage, before children are born, when the wife can contribute substantially to earnings. How much remains to be repaid and by whom, and how much asset holdings are rebuilt before the children are born, substantially influences the prospects of the household. How much marriage is a family rather than an individual undertaking obviously makes a great deal of difference. This varies considerably within as well as between social groups. 


\section{Housing}

Housing (house sites, houses, house improvements) is the other major investment in which a large number of landless agricultural labou rer households are involved. Landless agricultural labourers spend up to twice as much on housing as they spend on a good marriage. In theory agricultural labourers are entitled to government housing subsidies, but none in these villages had been able to take these up. ${ }^{4}$

Agricultural labourers mobilise resources for housing in similar ways to the mobilisation of resources for marriages, but where housing is concerned the onus is entirely on the young couple. Whether they have to consider investing in housing, and when, makes a great deal of difference to the long term opportunities of the couple and their chidren. If a young couple has to invest in housing, this can put them in a difficult net asset position from which it may not be easy to recover as dependency ratios deteriorate with the arrival of children. The risk of serious indebtedness is then very real. The availability of inherited housing makes it unnecessary for them to suffer a deterioration in their net asset position at a time when it may be particularly risky to do this.

There is a dramatic contrast between the housing standards of chakkiliyans and panadis in the Coimbatore villages. Chak kiliyans have been investing very considerably in housing and this is reflected in the relatively well-built, pucca housing they nearly all have as a result. Their house sites and surrounds are crowded, but there are very few dilapidated or cheap houses and there is relatively little overcrowding within the houses themselves. Panadis, in contrast, have cheap thatched houses with mud walls, many very dilapidated, and many very crowded inside. Caste hindu labourers' housing, most of it inherited, is somewhat better than chakkiliyans'.

\section{Livestock}

Livestock play a relatively important role in this area: bullocks are used very extensively for ploughing, and for transport, and milch animals are widespread. Livestock have been an important means of strengthening the position of agricultural labourers and others in India in the 1970s and 1980s. Agricultural labourers in the Coimbatore villages keep buffaloes, sheep and goats, pigs and chickens, but not bullocks, and very seldom milch animals. Many of the landless agricultural labourers who have most experience with cattle are considered unclean from the point of view of handling milk. Their cattle have to be milked by others if their milk is to be sold. Bullocks and carts and milch animals were the focus of the SFDA programmes in these villages in the late 1970s and the early 1980s. Landless agricultural labourers were effectively excluded from these

\footnotetext{
4 Hirway (1987) has a good discussion of the situation.
}

programmes however: this was partly because they were judged by the local cooperative leadership to be ineligible; also because the invest ments for which they might have been eligible were of little use in their circumstances [Heyer 1981]. Unlike in some parts of India, agricultural labourers do not hire themselves out with bullocks and carts, or bullocks and ploughs, in these villages. The terms of employment, the relatively easy availability of fodder and grazing on farms, and the discriminatory access to veterinary and other services, all undoubtedly play a part in making it attractive for farmers to keep their own bullocks, ploughs and carts instead.

Most agricultural labourers involved with livestock either rear buffaloes and cattle on a small scale, many on a share ownership basis, or keep sheep and goats. Sixty per cent of the agricultural labourer households in the sample had kept livestock at some stage; 44 per cent had some at the time of the study; half of these had some on a share basis.

Livestock are used as a means of accumulating savings over the medium term. They give some return, although they also involve an element of risk; and they are relatively liquid. They are more remunerative if there is some room for manoeuvre over when they are sold: thus they are better for financing marriage or housing expenditures which can be planned ahead, than for insurance against unforeseen emergencies such as illnesses or accidents. They appear to compare well with alternative savings instruments: financial assets, and gold and silver jewelry. The only 'financial assets' that these agricultural labourers have are loans out, and these only to a very small extent. They have very little jewelry. Consumer durables play a minor role as savings: few have good second-hand value in these communities.

\section{Land}

Agricultural labourers in these villages are not investing in land. Irrigated land, and the more productive rain-fed land is beyond their reach. Moreover, although one acre of land costs less than a good marriage, much less than a riew house, and less than an agricultural labourer's annual wage, it is quite costly to operate. Land may also limit agricultural labourers' ability to participate in the most lucrative wage labouring at peak seasons; and it may limit agricultural labourers' mobility.

It seems to have been possible for some landless households in the right caste groups to make a success of acquiring land in the past, but not now. Some agricultural labourers, all panadis, have very small amounts of land inherited from the past. They are not selling these: none are buying land either, however.

\section{Non-Agricultural Self-Employment}

Non-agricultural self-employment opportunities open 
to most households in these villages are limited to produce trading. retail trading. hotels. and bicycle shops. The traditional services of barbers. washernen. carpenters. blacksmiths. stonemalsons and potters are strictly limited to those of the right caste group. and there is a declining demand for these. Two of the self-employed outside the traditional services in the sample were ex-agricultural labourers. both caste hindus. one a petty shopkeeper. the other running a tea shop. Most non-agricultural self-employed came from landed families though none were from chakkiliyan or panadi households. There are opportunities being provided within the Integrated Rural Development Programme (IRDP), one of the successors to the SFDA, which helps underemployed rural people to start up in non-agricultural selfemployment. There was no evidence of any of this in the study villages in 1981-82 however.

\section{Education}

Access to education is a real problem for agricultural labourers, despite the fact that there are primary schools in all the villages, and a secondary school in one. Few boys from agricultural labourer households go to primary school for more than one or two years, and girls almost never go at all. Only 25 per cent of school-age boys in the landless agricultural labourer households in the sample had ever been to school; eight per cent had reached Standard V; four per cent had gone on to, but none had completed, secondary school. There were fewer in older age groups who had gone beyond the first few years of primary school. The free noon meals scheme introduced by the Tamil Nadu state government in 1981-82 is reported to have brought in large numbers hitherto excluded from school, but this was not yet in evidence at the time of the study. Nor is it clear that it is getting children much more access to education, even where it is bringing them in for the free meals [Harriss 1986].

Many agricultural labourers are entitled to some government financial support if they get beyond Standard V, and they get preferential access to a range of government jobs that require secondary or higher educational qualifications. However, there is no system of preferential treatment for agricultural labourers in the lower levels of the educational system, or in jobs that require primary education or less. Fifteen out of a total of 98 sons of agricultural labourer households in the sample who were 15 years or over had been to school. Six of these had found their education of some use in obtaining employment. The remaining nine were all agricultural labourers.

It is a major problem for the child of an agricultural labourer to get as far as Standard V or beyond in the Coimbatore villages. Children of agricultural labourers are not very successful when they get to school, and as soon as they are old enough to be sent out to work most are taken away. Many will already have given up before this. (Reasons for leaving school were variously given as because the child had had a try and proved not to be making a success of it: because the child concerned was reluctant to continue: and/or because the child concerned was needed to work.)

The costs of schooling. implicit or explicit. even at the primary level. are large relative to the earning capacities of agricultural labourer households. The period over which they have to be borne is long. and the risks of failure along the way are very substantial. One person from an agricultural labourer household (not in the sample) in one of the study villages managed to complete secondary school and beyond: $\mathrm{He}$ is now an agricultural assistant. The household concerned made tremendous sacrifices over a period of 10 years or more before the son obtained employment that reflected the qualifications he had acquired. It was easy to see why others were unable or unwilling to emulate this.

What needs explaining is the fact that in other parts of India the situation appears to be better [Subbarao 1987; Kumar 1983; Saradamoni 1981]. In the Coimbatore villages the extreme social differentiation may help to explain why it is so difficult for chakkiliyan or panadi children to succeed in school. The relatively good agricultural labour market also makes the opportunity cost of school high, and agricultural labouring a reasonable option, for those who do not go to school. Furthermore, there is the very low level of political mobilisation. All of these certainly contribute to an appallingly low level of education where agricultural labourers' children are concerned.

\section{Migration}

Migration also appears to provide limited opportunities for agricultural labourers in these villages. Of the 98 sons of agricultural labourers in the sample who were 15 years or over, 10 were living or working away. These include an unskilled labourer in Coimbatore, a water-seller and two petty traders in smaller nearby towns, someone who migrated near Ootacamund in the Nilgiris Hills where he could make a success of owning land, three people working in textile mills, and a clerk with the Coimbatore Electricity Board. The majority of these are from caste hindu households. It is rare for sons from chakkiliyan or panadi households to move away. The relatively plentiful opportunities for agricult ural labour in these villages tip the balance in favour of staying, rather than moving away.

\section{General Points}

Thus, for these agricultural labourers, in a relatively 'progressive' area, the obviously high priority 'investments' are marriage and housing. A few have invested in migration; a few in education; very few in non-agricultural self-employment; none recently in 
land. F.w of these investments make landless agricultural labourers dramatically bettcr off. in cither the short or long term. Housing and marriage investments may increase the quality of labour. sometimes rather indircctly. Education investmonts incrcase the quality of labour of the very tiny minority. Direct investments in health hardly featurc at all. There is very little that is obviously directly productive. It may be that better health. less vuln $r$ rability. etc. arc improving the quality of labour. but this is not obvions. The situation in these villages is not notably diffirent from that elsewhere in India in this respect [Jose 1988]. And to the extent that there is any improvement. What is happ.ning on the demand side is probably more important than what is happening to supply. However. the gradual increase in quality of labour that is taking place may play some role in determining the earning possibilities of labourers: it is also of some benefit in its own right. Small gains that accumulate almost imperceptibly are easy to underestimate.

Alternative ways of improving the situation of some of these landless agricultural labourers may include nonagricultural opportunities. But the problem is not just. or even always primarily, a problem of finance, as so many government programmes seem to assume. It is as much a problem of weak incentives. More efforts need to be made to create an environment in which landless agricultural labourers assets can be more productive. More efforts also need to be made to enable the children of landless agricultural labourers to get something of real substance, with real content, from the educational system. Government programmes need to put more emphasis on these other aspects if their existing emphasis on finance is to be successful where landless agricultural labourers are concerned.

\section{Conclusions}

Even in India, whcre direct government intervention has put a strong emphasis on improving the asset positions of landless agricultural labourers and others among the poor. landless agricultural labourer investment strategies are poorly understood. The failure to take seriously what landless agricultural labourers are doing leads to missed opportunities. and poor policy performance. Asset strategies are misunderstood by outsiders, who ignore them because they think they are unimportant. and /or try to change them because they think they know which invest ments are 'better' for landless agricultural labourers and for society more generally. But here. as in other areas. one needs to understand to intervene successfully. Studies of what people do, and why their priorities are as they are, even if they seem perverse, are a necessary starting point. Building on what is already there may have a better chance of success than more radical intervention based on tabula rasa assumptions.

\section{References}

Bandopadlus ax. 1).. 1988. 'Dircet intervention programmes for poucty alleviation: an appraisal'. $L P P^{\prime}$. vol 23 . no 26. Junc 25

Bardhan. K.. 1985. 'Womcn's work. Welfare and status'. EPW. vol 20. no 50. December 14

Chambers. R. and Leach. M. 1987. "Trecs to meet contingencies: a strategy for the rural poor?'. Discussion Paper 228. IDS. Sussex. January

Dantwala. M. L.. 'Garibi hatao: strategy options'. 1985. ISPW. vol 20. so 11. March 16

Guhan. S. 1980. 'Policy and play acting' EPW' vol 15 no 47. November 22

-1986. 'Reaching ont to the poor'. Economic Times. December 19

Harriss. B.. 1986. 'Mcials and noon meils in South India: food and nutrition policy in the rural food coonomy of Tamil Nadu Statc: Occasional Paper 31. School of Development Studics. University of East Anglia

Heycr. J.. 1981. 'Attcmpting to reach the rural poor'? The Small Farmer Devclopment Agency in Varandur Village. Coimbator: . Working Paper No. 22. Madras Institute of Divelopment Studies

Hirway. 1.. 1987. 'Housing for the rural poor'. EPW. vol 22. no 34. August 22

- 'Garibi hatao: can IRDP do it?'. 1985. EPW. vol 20. no 13. March 30

Jodha. N. S.. forthcoming. 'Social science research on rural change: some gaps". in P. Bardhan (ed.). Rural Economic' Change in South Asia: Methodology' of Measurement

Josc. A. V.. 1988. 'Agricultural wages in India'. EPW. vol 23. no 26 . June 25

Kumar. K.. 1983. 'Educational experience of scheduled castes and tribes". EPW, vol 18. no 36-37. September 3-10

Kurian. N. J.. 1987. 'IRDP: how relevant is it?'. EPW, vol 22. no 52 . December 26

Parthisarathy. G.. 1985. 'Reorientation of rural developmont programmes: a notc on some basic issiles", $E P W$. vol 20. no 48 . November 30

Prasad. P. H.. 1985. 'Poverty and agricultural development'. $E / W$. vol 20. no 50. Decimber 14

Rao. V. M. and Erappa. S.. 1987. 'IRDP and rural diversification: a study in Karnataka. EPW. vol 22. no 52. December 26

Rath. N.. 'Garibi hatao: can IRDP do it?'. 1985. EPW. vol 20. no 6. February 9

Rudra. A.. 1987. 'Labour relations in agriculture: a study in contrasts'. EPW. vol 22. no 17. April 25 
Saradamoni, K.. 1981. Educition. employment, and latnd ownership. role of caste and econemic factors. EPW. vol 16. no 36. September 5

Sivakumar. S. S. 1978. Aspects of agrarian cconomy in Tamil Nadu: al study of two villages, Part 1II, EPH', vol 13. no 20. Maay 20

Subbarao. K., 1985. 'Regionall vartiations in impact of anti- poverty programmes: al review of evidence". $E P W$, vol 20. no 43 . October 26

-1987. "Some aspects of access to education in Indial. Workshop on Poverty in India. Queen Elizabeth House. Oxford. Scptember

Unni. J.. 1988. 'Agricultural labourers in rural labour houscholds, 1956-7 to 1977-8: changes in emplovment. wilges and incomes", $E P W$, vol 23 , no 26, June 25 